\title{
Beware of UVC sanitizers: not all are good
}

\section{Ojo con los sistemas de desinfección de UVC: no todos son buenos}

\author{
Justo Arines ${ }^{1}$, Carmen Bao-Varela ${ }^{1,2}$ \\ 1. Facultade de Óptica e Optometría, Universidade de Santiago de Compostela, España \\ 2. Facultade de Física, Universidade de Santiago de Compostela, España \\ (*)E-mail: justo.arines@usc.es_S: miembro de SEDOPTICA / SEDOPTICA member \\ Received: 09/09/2020 Accepted: 18/09/2020 \\ DOI: $10.7149 /$ OPA.53.3.51044
}

\begin{abstract}
:
Disinfection is now one of the major concerns of society. Soap, or hydroalcohol are two known ways of sanitizing different objects. Now we can find in the market more sophisticated systems, which provide more confidence on their sanitizing effects, or that allows disinfection of objects that cannot be sanitized with soap or hydroalcoholic solutions. In this work we analyze a commercially available sanitizing device that claims the use of UVC radiation. We will show that this device is not suitable for complete disinfection of the objects introduced on the cabin. We provide spectral characterization of the sources, as well as irradiance measurements inside the cabin. We conclude that the cabin cannot be used for sanitizing most of the objects that are included in the documentation of the device.
\end{abstract}

Key words: UVC, Germicidal radiation, Disinfection.

\section{RESUMEN:}

La desinfección es actualmente una de las principales preocupaciones de la sociedad. Tanto el jabón como el gel hidroalcohólico son dos métodos de limpieza empleados. Además, podemos encontrar en el mercado sistemas más sofisticados que dan una mayor sensación de desinfección y confianza, o que por otra parte pueden ser usados en objetos que no pueden ser desinfectados con líquidos. En este trabajo analizamos una cabina de desinfección que actualmente puede ser encontrada en tiendas locales o internet, basadas en el uso de radiación UVC. Mostraremos que la cabina no es adecuada para proporcionar la desinfección de la que hace gala. Proporcionaremos información sobre los espectros de emisión de los LEDs que emplea, medidas de irradiancia y dosis proporcionadas en los 5 minutos de exposición que proporciona el aparato. Concluiremos que la cabina no debe ser usada para desinfectar los objetos para los que se ha diseñado, indicados en la documentación del dispositivo.

Only for Spanish speaking authors.

Palabras clave: UVC, desinfección, SARS-CoV-2, Espectroradiómetro

\section{REFERENCES AND LINKS / REFERENCIAS Y ENLACES}

[1] A. Cabaj, et. al., Ultraviolet air disinfection, CIE 155:2003 ISBN: 9783901906251 (2003).

[2] Jean-Pierre Cesarini, et. al., UV-C photocarcinogenesis risks from germicidal lamps, CIE 187:2010, ISBN: 9783901906817 (2010).

[3] Chevrefils, G., Caron, É., Wright, H., Sakamoto, G., Payment, P., Barbeau, B., \& Cairns, B. “UV dose required to achieve incremental log inactivation of bacteria, protozoa and viruses". IUVA News, 8(1), 38-45 (2006).

[4] Patricia Carol Gil, Asher Gil, Daniel Gil, "System for Sterilizing Objects Utilizing Germicidal UV-C Radiation and Ozone", Patent WO 2016/060855 Al (2016)

[5] Heßling, Martin, et al. "Ultraviolet irradiation doses for coronavirus inactivation-review and analysis of coronavirus photoinactivation studies," GMS hygiene and infection control 15 (2020). 
[6] Sabino, C. P., Ball, A. R., Baptista, M. S., Dai, T., Hamblin, M. R., Ribeiro, M. S., ... \& Wainwright, M. "Lightbased technologies for management of COVID-19 pandemic crisis", Journal of Photochemistry and Photobiology B: Biology, 111999 (2020).

[7] Hiroko Inagaki, Akatsuki Saito, Hironobu Sugiyama, Tamaki Okabayashi \& Shouichi Fujimoto, "Rapid inactivation of SARS-CoV-2 with deep-UV LED irradiation", Emerging Microbes \& Infections, 9:1, 17441747 (2020)

[8] Bianco, A., Biasin, M., Pareschi, G., Cavalleri, A., Cavatorta, C., \& Fenizia, C. "UV-C irradiation is highly effective in inactivating and inhibiting SARS-CoV-2 replication".

[9] Heilingloh, Christiane Silke, et al. "Susceptibility of SARS-CoV-2 to UV Irradiation", American Journal of Infection Control (2020).

[10] Schuit, Michael, et al. "Airborne SARS-CoV-2 is Rapidly Inactivated by Simulated Sunlight." The Journal of Infectious Diseases, Volume 222, Issue 4, 15, 564-571 (2020).

[11] Rezaie A, Leite GGS, Melmed GY, Mathur R, Villanueva-Millan MJ, Parodi G, et al. "Ultraviolet A light effectively reduces bacteria and viruses including coronavirus". PLoS ONE 15(7): e0236199 (2020).

[12] Tomb, Rachael M., et al. "Review of the comparative susceptibility of microbial species to photoinactivation using 380-480 nm violet-blue light." Photochemistry and photobiology 94.3 445458 (2018).

[13] She, Rosemary C., et al. Lightweight UV-C disinfection system., Biomedical Optics Express, 11.8, 43264332 (2020).

[14] Baluja, A., Arines, J., Vilanova, R., Cortiñas, J., Bao-Varela, C., \& Flores-Arias, M. T. “UV light dosage distribution over irregular respirator surfaces. Methods and implications for safety". Journal of Occupational and Environmental Hygiene, 1-8 (2020).

\section{Introduction}

In these days, disinfection of daily used objects, like keys or mobile phones has increased significantly due to the concern on being infected with SARS-CoV-2. Added to soap or hydroalcoholic solutions, more sophisticated devices have been used, as ozone machines or UVC sterilizing cabins. A fast search in the internet provides a plethora of commercial disinfection UVC cabins of different sizes, materials, and prizes. From this variety, we highlight the product oriented to the disinfection of personal equipment, mobile phones, keys, rings... currently available in local shops, or in electronic commerce. These devices promise to disinfect the objects placed inside in a determined interval of time by using UVC radiation. Some of them, even pledge to disinfect in all directions, killing bacteria, fungi and virus.

UVC or UV germicidal radiation comprises de wavelength range (100 nm-280 nm) [1,2]. At these wavelengths, the photons present energy enough to be absorbed by the DNA or RNA bases limiting the capability of replication of microorganisms. Out of this range, it is also possible to inactivate microorganisms. For example, in the case of bacteria, radiation named violet-blue (380-480 nm) induce the creation of reactive oxygen species due to the absorption of photons by porphyrin molecules [3].

Disinfection not only depends on the wavelength but also on the dose (irradiance $\mathrm{x}$ time), which also depends on the pathogen [4-6]. Recent works performed using UVC on SARS-CoV-2 showed various doses. The work of Hiroko Inagaki [7] proposes a dose of $37 \mathrm{~mJ} / \mathrm{cm}^{2}$ using UVC of $280 \mathrm{~nm}$. The work of Andrea Bianco [8] proposes a dose of $6.7 \mathrm{~mJ} / \mathrm{cm}^{2}$ using a source of $254 \mathrm{~nm}$. Other work performed by Christiane Heilingloh [9] employing highly concentrated virus solution suggest a dose close to $1 \mathrm{~J} / \mathrm{cm}^{2}$ (using UVC of $254 \mathrm{~nm}$ ) to completely inactive the virus.

Studies on inactivation of microorganisms using UVB and UVA show even higher doses. In reference [10] Schuit et. al. concluded that with a dose around $3800 \mathrm{~mJ} / \mathrm{cm}^{2}$ of UVA it is possible to achieve a reduction of the $90 \%$ of SARS-CoV-2. Concerning other microorganisms Rezaie et.al. [11] analyses the response to UVA. As an example, they show that for inactivating Escherichia Coli a dose of $3600 \mathrm{~mJ} / \mathrm{cm}^{2}$ is needed. On the other hand, in the work of Tomb et al. [12] concerning the wavelength range known as violet-blue (380 $500 \mathrm{~nm}$ ) we can find a review of different doses depending on the microorganism. In this review we could not find microorganism inactivation with doses inferior to $4 \mathrm{~J} / \mathrm{cm}^{2}$. 
Recently, due to Covid-19 pandemic, and the need of masks disinfection, different studies have been published showing UVC cabin disinfection systems [13-14] and the relevance of the cabin design for providing uniform irradiance distribution on the object to be disinfected.

In the present manuscript we analyze a commercial disinfection cabin. In section 2 we present the experimental setup. Section 3 is devoted to results, while in section 4 we discuss the results. Finally, in section 5 we present the conclusions.

\section{Experimental setup}

The sanitizing chamber is a "UV sterilizer" bought in a local mall (see fig. 1). It is sold for disinfecting, mobile phones up to 7 inches, keys, rings... It claims a $360^{\circ}$ object sterilization. The manual indicates a working wavelength of $253 \mathrm{~nm}$. The time for disinfection is 5 minutes. The manual advices that the shadowed areas of the objects placed inside the chamber might not be disinfected. To operate the cabin, first we put the object inside, secondly close the cover, and press the Sterilize button. Important to notice that the cabin can be operated with the cover open, no security interlock is present in the system.

In figure 1 we show a picture of the sanitizing cabin. The inner part used for disinfection is $17.8 \mathrm{~cm} \times 10.8$ $\mathrm{cm}$. It presents 10 LEDs, 7 of type 1, 1 of type 2, and 2 of type 3 (in next section we show their emission spectra). Only type 2 LED emits in the UVC region.

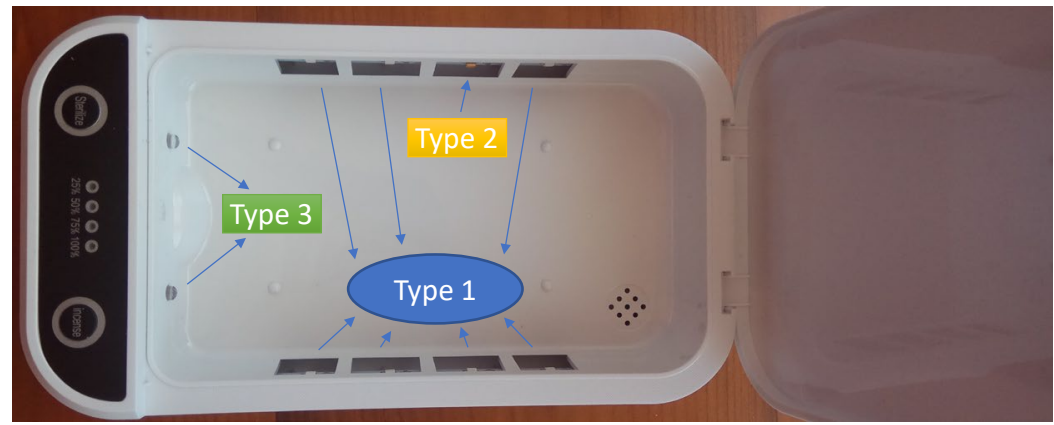

Fig.1. Sanitizing cabin with 3 types of LEDs

Figure 2 shows the cabin working with a melamine perforated plate to simulate a mobile model, with the spectrum probe placed on one of the holes for measuring the irradiation in that position at the bottom surface of the mobile model. The holes in the model are for placing the spectrometer probe in different parts of the mobile model.

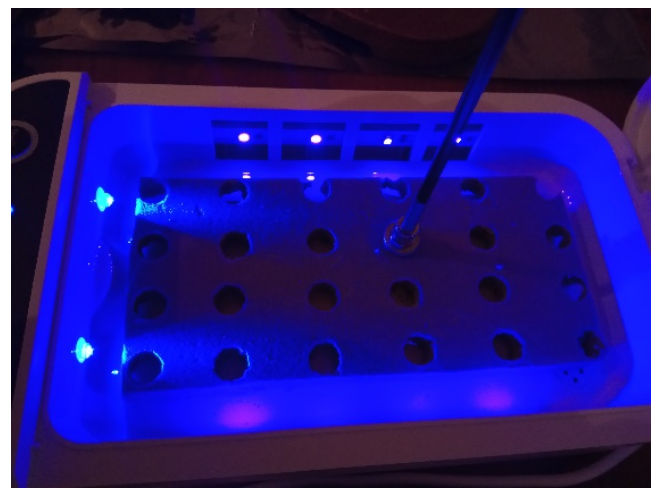

Fig.2. Sanitizing chamber with mobile phone model and spectrum probe.

The measurements were performed with the radiometrically calibrated spectroradiometer, SILVERNOVA from StellarNet. This spectrometer presents a measurement range between $193 \mathrm{~nm}$ and $1100 \mathrm{~nm}$. The 
integration time was adjusted using the SCOPE mode, to avoid detector saturation and achieve a range of 45.000 bins at the maximum irradiance.

We performed two different sets of measurements. First group of measurements consisted of measuring the irradiance at the lateral of the mobile phone model. In doing that we defined 12 positions shown in figure 3. The separation between the lateral of the chamber and the probe was $5 \mathrm{~mm}$.

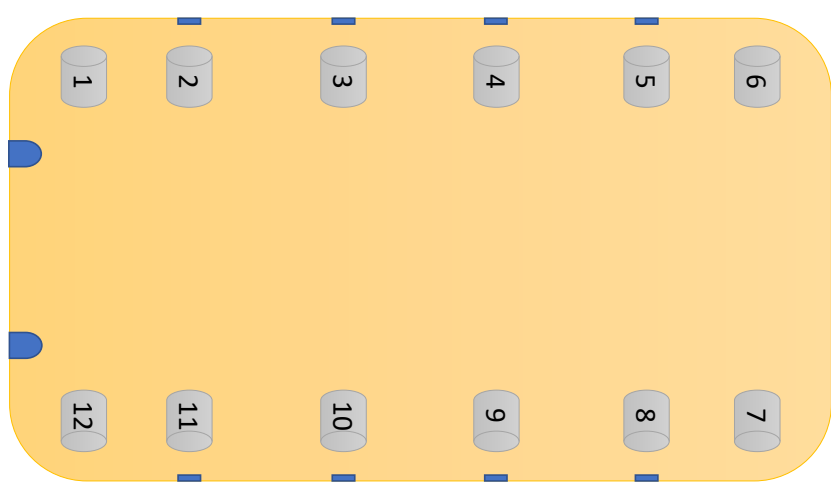

Fig.3. Outline of the lateral irradiance measurements.

We also measured the irradiance at the bottom surface of the mobile phone model. We measured in front of the type 2 LED indicated in fig 1, in the positions shown in figure 4. Measurements in other positions were initially planned, but after an initial round of measurements we found that they were not necessary.

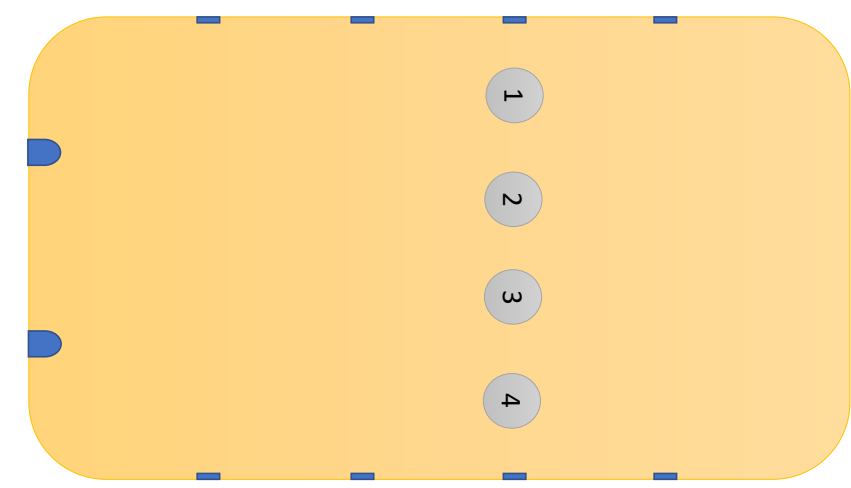

Fig.4. Outline of the irradiance measurements at the bottom of the mobile phone model.

\section{Results}

First, we measured the spectrum of the LEDs, finding that the sanitizing chamber presents three types of LEDs in terms of their emission spectra. In figure 5 we present their measured spectra. Type 1 presents a monomodal emission spectrum with a peak at $397.85 \mathrm{~nm}$ and a FWHM of $13.27 \mathrm{~nm}$; Type 2 presents a bimodal emission spectrum with the first maximum at $282 \mathrm{~nm}$ with a FWHM of $12.09 \mathrm{~nm}$, and a second maximum at $401 \mathrm{~nm}$ with a FWHM of $13.27 \mathrm{~nm}$; Type 3 is a monomodal spectrum with maximum at 464 $\mathrm{nm}$ and FWHM of $19.70 \mathrm{~nm}$. So, in the studied disinfection chamber only just one LED emits in the UVC region, and far from the $253 \mathrm{~nm}$ emission wavelength clamed in the manual of the device. 
ÓPTICA PURA Y APLICADA

www.sedoptica.es

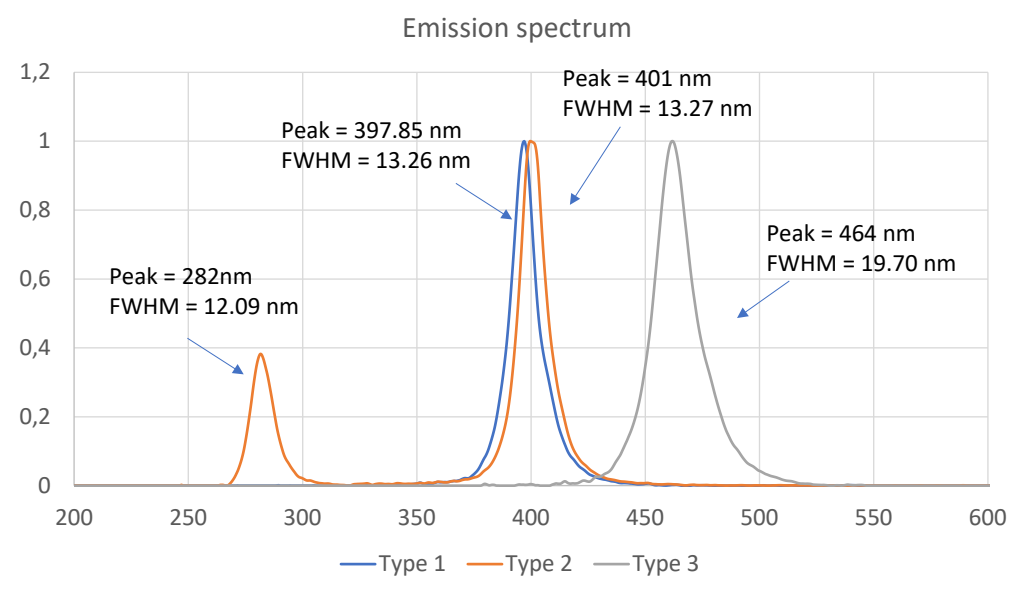

Fig.5. Emission spectra of the three types of LEDs in the disinfection chamber.

In table 1 we present the irradiance measured at the lateral of the mobile phone model at $5 \mathrm{~mm}$ of the walls of the chamber and in positions indicated in figure 3. We measured the irradiance in three different spectral ranges: first range (250-300) nm containing the first emission lobe of type 2 LED, which have potential biocidal properties; second range blue-violet (380-480)nm; and a third range (250-600) nm containing all the emission spectrum of the three types of LEDs.

Table 1: Irradiance $\left(\mu \mathrm{W} / \mathrm{cm}^{2}\right)$ at $5 \mathrm{~mm}$, at the specified wavelength range $(\mathrm{nm})$

\begin{tabular}{|c|c|c|c|c|c|c|c|c|c|c|c|c|}
\hline Position & $\mathbf{1}$ & $\mathbf{2}$ & $\mathbf{3}$ & $\mathbf{4}$ & $\mathbf{5}$ & $\mathbf{6}$ & $\mathbf{7}$ & $\mathbf{8}$ & $\mathbf{9}$ & $\mathbf{1 0}$ & $\mathbf{1 1}$ & $\mathbf{1 2}$ \\
\hline $\mathbf{2 5 0 - 3 0 0 n m}$ & 0 & 10.87 & 19.99 & 1217.61 & 19.3 & 0.11 & 0.04 & 28.44 & 19.37 & 17.32 & 10.88 & 0 \\
\hline $\mathbf{3 8 0 - 4 8 0 n m}$ & 101.47 & 1819.31 & 2199.30 & 3396.40 & 2844.09 & 37.66 & 65.17 & 3813.41 & 3280.50 & 3183.55 & 2635.75 & 97.33 \\
\hline $\mathbf{2 5 0 - 6 0 0 n m}$ & 101.47 & 1830.18 & 2218.69 & 4614.01 & 2863.39 & 37.77 & 65.21 & 3841.85 & 3299.87 & 3200.87 & 2646.63 & 97.33 \\
\hline
\end{tabular}

Figure 6 shows the data of table 1 in a graph of bars in order to better visualize the data.

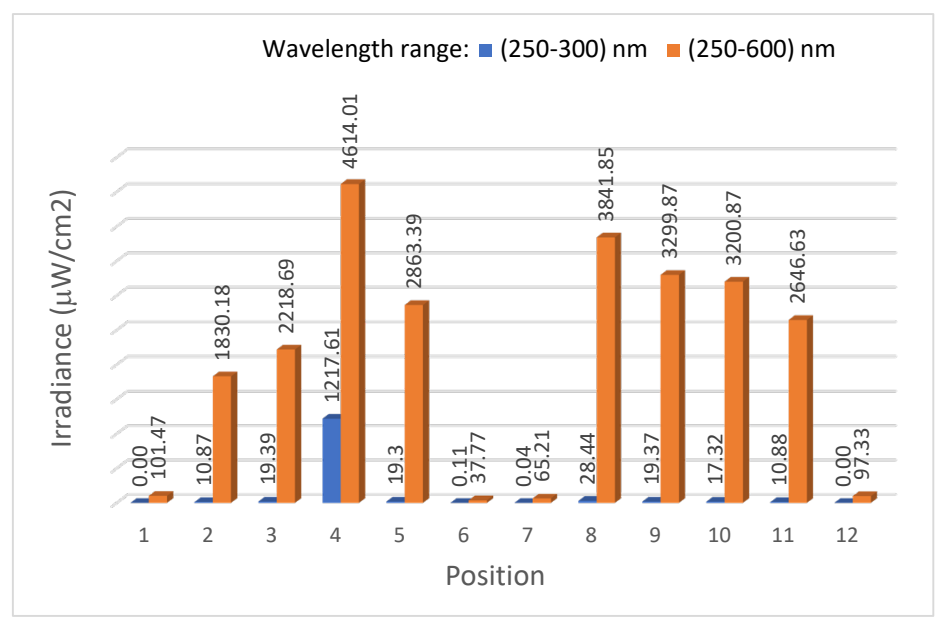

Fig.6. Irradiance measured at the positions described in figure 3, in two wavelength ranges: blue $(250,300) \mathrm{nm}$; red $(250,600) \mathrm{nm}$. 
Table 2 presents the dose achieved in the 5 minutes in which the device is working for disinfection, in the twelve positions indicated in figure 3 and the spectral ranges described before. Remember that the dose can be calculated using the next expression (Dose = Irradiance $\mathrm{x}$ time (s)).

Table 2: Dose $\left(\mathrm{mJ} / \mathrm{cm}^{2}\right)$ at $5 \mathrm{~mm}$, at the specified wavelength range $(\mathrm{nm})$. Integration time $5 \mathrm{~min}$

\begin{tabular}{|l|l|l|l|l|l|l|l|l|l|l|l|l|}
\hline Position & $\mathbf{1}$ & $\mathbf{2}$ & $\mathbf{3}$ & $\mathbf{4}$ & $\mathbf{5}$ & $\mathbf{6}$ & $\mathbf{7}$ & $\mathbf{8}$ & $\mathbf{9}$ & $\mathbf{1 0}$ & $\mathbf{1 1}$ & $\mathbf{1 2}$ \\
\hline $\mathbf{2 5 0 - 3 0 0 n m}$ & 0 & 3.26 & 5.82 & 365.28 & 5.79 & 0.03 & 0.01 & 8.53 & 5.81 & 5.19 & 3.26 & 0 \\
\hline $\mathbf{3 8 0 - 4 8 0 n m}$ & 30.44 & 545.79 & 659.79 & 1018.92 & 853.227 & 11.29 & 19.55 & 1144.02 & 984.15 & 955.06 & 790.72 & 29.20 \\
\hline $\mathbf{2 5 0 - 6 0 0 n m}$ & 30.44 & 549.05 & 665.61 & 1384.20 & 859.02 & 11.33 & 19.56 & 1152.55 & 989.96 & 960.26 & 793.99 & 29.20 \\
\hline
\end{tabular}

Table 3 shows the irradiance measured and dose obtained in 5 minutes of exposure at the bottom of the mobile phone model at the positions on figure 4, for the spectral ranges described previously.

Table 3: Irradiance $\left(\mu \mathrm{W} / \mathrm{cm}^{2}\right)$; Dose $\left(\mathrm{mJ} / \mathrm{cm}^{2}\right)$ at $5 \mathrm{~mm}$, at the specified wavelength range $(\mathrm{nm})$

\begin{tabular}{|c|c|c|c|c|}
\hline Position & $\mathbf{1}$ & $\mathbf{2}$ & $\mathbf{3}$ & $\mathbf{4}$ \\
\hline $\mathbf{( 2 5 0 - 3 0 0 )} \mathbf{~ n m}$ & $0.02 ; 0.004$ & $0 ; 0$ & $0 ; 0$ & $0 ; 0$ \\
\hline$(\mathbf{2 5 0 - 6 0 0 )} \mathbf{~ n m}$ & $10.72 ; 3.216$ & $0.94 ; 0.288$ & $0.48 ; 0.144$ & $2.77 ; 0.831$ \\
\hline
\end{tabular}

\section{Discussion}

Covid-19 pandemic has created a new trend in community consumption. Manufacturers and sellers took advantage of the awareness of society with sterilization of objects. Newspapers published and continue to publish frauds concerning sanitizing liquids and devices (as for example face masks which do not protect against the virus). In this work we analyzed a sterilization device which claims to use UVC light at $253.7 \mathrm{~nm}$ to sterilize current objects as keys, watches, or mobile phones.

First, we found that the emission wavelength of the LEDs present in the device are far from the $253.7 \mathrm{~nm}$ claimed. This wavelength is associated with the emission wavelength of the mercury lamps which are mostly used for sanitization. So, we think that claiming that the device uses this wavelength is just a commercial hook. Just only one of the 8 LEDs supposed to emit UVC light, emits in this range (LED type 2 whose emission spectrum is shown in figure 5). The other 9 LEDs (type 1 and 2) emits in the band region around 400 and $470 \mathrm{~nm}$ known as blue-violet region.

Second, we found a high difference in the irradiance and dose achieved at different parts of the sterilizing cabin (see figure 6 and tables 1,2 and 3). Comparing the data of table 1 and 3 we observe that in the irradiance at the cabin in the UVC range is negligible excepting the vicinity of the UVC LED. So, virus disinfection might not be correctly achieved with this device. All studies on disinfection recommend a dose of UVC above $6.7 \mathrm{~mJ} / \mathrm{cm}^{2}$ for Covid-19 disinfection, and higher for more complex virus [5-10]. Considering the doses achieving during the 5 minutes irradiation, the cabin provides enough dose only in front of the UVC LED. In any other position the dose is not enough for achieving the claimed sterilization. On the other hand, if we face the possibility of disinfecting using UVA, we have to compare the achieved dose, with those recommended in the literature. Reference [10] indicates that with a dose close to $3800 \mathrm{~mJ} / \mathrm{cm}^{2}$ of UVA is possible to achieve a reduction of $90 \%$ of Sars-CoV-2. Reference [11] analyzes other microorganisms, showing for example that a dose of $3600 \mathrm{~mJ} / \mathrm{cm}^{2}$ in the UVA range is needed for inactivating Escherichia Coli. Besides the work of R. Tomb et.al. [12] on UVA in the range of 380-480 nm shows that inactivation of microorganisms in this range needs more than $4000 \mathrm{~mJ} / \mathrm{cm}^{2}$. In this range the cabin under study provides a maximum of $1144.02 \mathrm{~mJ} / \mathrm{cm}^{2}$ in front of LED position 8 at $5 \mathrm{~mm}$ of the lateral LEDs. So, not enough dose is achieved neither at the UVC range nor at the UVA for sterilizing any object placed inside the cabin. 


\section{Conclusions}

The most important conclusion of this work is that we should be aware of what is sell for disinfection. The design of the disinfection cabin has proven to fail, generating an irradiance distribution with very high differences in terms of irradiance, and shadows that do not provide uniform disinfection of the surfaces of the objects placed inside. Additionally, the dose achieved in the 5 minutes of the disinfection treatment is insufficient for disinfection in accordance with the dose recommended in the literature for microorganisms and Sars-Cov-2 inactivation either at the UVC and UVA ranges.

\section{Acknowledgements}

This work was supported by the Spanish Ministry of Economía y Competitividad FIS2016-77319-C2-1-R, Consellería de Educación Program for Development of a Strategic Grouping in Materials - AeMAT Grant No. ED431E2018/ 08 and Xunta de Galicia ref. ED431B2017/64. 